\title{
Investigating Drama in Teaching Practice
}

\author{
SENIARIKA ${ }^{\mathbf{1}}$ \\ seniarika157@gmail.com \\ Islamic State University Raden Intan Lampung
}

\begin{abstract}
Drama is widely used in English class inasmuch as drama is considered as a way to learn English effectively. A lot of researcher conducted studies on drama either aimed to find out the benefits obtained through drama or aimed to find out the difficulties that might be found by the learners in drama. This article reviews five articles in relation with drama. The researcher in those studies investigated drama from different perspective. The result found in this study is expected to be consideration in implementing drama in teaching practice.
\end{abstract}

Keywords: Drama activities, drama techniques, drama benefits

\section{INTRODUCTION}

English class is demanded not only enhancing English skills but also cultivating critical thinking and character building; here drama can effectively deal with this requirement. Critical thinking is selfdirected, self-disciplined, self-monitored, and self-corrective thinking. It presupposes assent to rigorous standards of excellence and mindful command of their use. It entails effective communication and problemsolving abilities, as well as a commitment to overcome our native egocentrism and sociocentrism.

Someone with critical thinking skills is able to understand the logical connections between ideas; identify, construct and evaluate arguments; detect inconsistencies and common mistakes in reasoning; solve problems systematically; identify the relevance and importance of ideas; reflect on the justification of one's own beliefs and values.

Abraham Lincoln said, "Reputation is the shadow. Character is the tree." Our character is much more than just what we try to display for others to see, it is who we are even when no one is watching. Good character is doing the right thing because it is right to do what is right.

The dictionary definitions said character is a "complex of mental and ethical traits", that those traits, or qualities, are "distinctive to an individual" and that 
they are "built into an individual's life." It is those character qualities, those character traits, that determine a person's response in any given situation. For example, a person in with a strong character quality of truthfulness is much more likely to accurately report the facts in a given situation than a person who tends to be characterized by deceptiveness. Someone who has the character trait of alertness will be more likely to be a better, safer, driver than a person who does not see or recognize the potential dangers around him (carelessness). A person with the character quality of tolerance will be more accepting of others - less prejudiced.

Having known how critical thingking and character building are needed, English teachers are suggested to create or use methods that can not only enhancing learners' English proficiency but also cultivating learners' critical thinking and character building.

Numerous researchers investigated drama from different perspective (Zyoud, 2011; RaghianAlbalawi, Bashayer, 2014; Moghaddas and Ghafariniae, 2012; Shokri and Philip, 2014; Shakfa, 2012). They found that drama gives benefits for learners either English learners or non-English learners. However they also found that there are some obstacles found by learners when they are trying to understand drama.

\section{DISCUSSION}

\section{Drama to foster teaching English as a}

foreign language.

Zyoud (2011) in his article elaborated on how Drama can foster language skills such as reading, writing, speaking and listening by creating a suitable context. He also added that drama fosters and maintains students' motivation, by providing an atmosphere which is full of fun and entertainment.

In his article, he explained four drama activities that can be done in teaching practice; mime, role play, simulation, and improvisation.

\section{Mime}

Mime emphasizes the paralinguistic features of communication. It builds up the confidence of learners by encouraging them to get up and do things in front of one another. The procedure of miming is the students are working in pairs or small groups, students are given topics to work on which are to form the basis of a three minute mime (a burglary that goes wrong, an incident at a bus stop, an argument at the cinema, for example), five minutes are 
allowed for preparing and rehearsing. Students perform their mime in turn, and after each performance the teacher asks the class to interpret what it has been.

\section{Role play}

The main benefit of role play from the point of view of language teaching is that it enables a flow of language to be produced that might be otherwise difficult or impossible to create. By simulating reality, role play allows students to prepare and practice for possible future situations. Ideas for role play could be obtained from situations that teachers and learners experience in their own lives, from books, television programmes and movies or from their daily interactions with other people at school/ university or in the work place. After choosing a context for a role play, the next step to follow is to provide ideas on how this situation may develop. It is important to take into consideration the learners' level of language proficiency when using and implementing role play activities in the classroom.

There are many types of role play. Dramatic plays, story dramatization and sociodrama, seminar style presentation, debates and interview. They range from beginners, role play for weaker students to advanced role play for the more proficient students. Different types of role play demand different approaches, the way the role play is introduced, the description of the roles, the facilitation and debriefing sessions vary accordingly.

\section{Simulation}

A simulation activity is one where the learners discuss a problem within a defined setting. In simulation activities, the students are either playing themselves or someone else. Simulation activities are also interaction activities with various categories of dialogues. One category would be social formulas and dialogues such as greeting, parting, introductions, compliments, and complaints. Simulation exercises can teach students how to function in a social situation with the appropriate social niceties: for example, students could practice how to turn down a request for a date or a party.

Another category of simulated interaction activity is community oriented tasks, where students learn how to cope with shopping, buying a ticket at a bus stop etc. This sort of simulation helps students' communicative participation in the community and at the very least helps them in the task of collecting important information. A clear line cannot be drawn 
between role play and simulation. These two drama activities overlap. Role play is frequently used within simulation in rolesimulation. The participant remains the same individual while reacting to a task that has been simulated on the basis of his own personal or professional experience.

The function of a simulation is to give participants the opportunity to practice taking on specific roles and improvising within specific situations on the assumption that with practice the participants will play their roles more effectively when situations involving similar skills occur in real life. Using given details of the relevant aspects of situation, participants have to make decisions or come to some agreement or resolve a problem, thus meeting a challenge posed by the simulated situation.

However behaviour is not controlled in a simulation and the participants bring to the situation their own skills, experience and knowledge. Simulation can be effectively applied to a course called English for Specific Purposes, because in ESP classes, simulations are particularly useful in practicing and evaluating the use of procedures and language (vocabulary, and structures) specific to particular skills.

\section{Improvisation}

Improvisation is an excellent technique to use in the FL/L2 classroom as it motivates the learners to be active participants in authentic situations thereby reducing their self consciousness. At the beginning students will be hesitant and shy to participate in the activities, but after a few sessions they will become more enthusiastic and there will be a phenomenal improvement in their confidence level.

Improvisation exercises could involve an entire class of learners or smaller groups. Spontaneous improvisation gives learners practice in language and communication skills, and they have the opportunity to develop their emotional range by playing roles unfamiliar to them and outside their own experience.

\section{Drama on the development of students' creative thinking.}

RaghianAlbalawi, Bashayer (2014) investigated the influence of teaching English subject using drama on the development of intermediate students' creative thinking. According to his perception creative thinking is related to the three main skills of fluency, creativity and originality. After dealing with the procedure which involves two randomly selected first 
year intermediate classes of the 33 intermediate female schools $(\mathrm{N}=24$ students in control group class, $\mathrm{N}=23$ students in experimental group class), he found that teaching English subject using drama is effective in the development of first year intermediate students' creative thinking.

\section{Drama techniques in teaching English.}

Moghaddas and Ghafariniae (2012) stated that there were a few examples of diverse drama activities for teachers to incorporate into their teaching repertoire. By having a taste of creativity and imagination, teachers can adjust these activities to their students' level or come up with some other forms of drama activities.

1. Body talk, no words or sounds, (elementary levels).

The teacher shows some basic actions or expressions (such as I am happy / sad/ strong/ cold/ hungry/ etc.) and then the students respond by imitating the teacher.

2. Going a trip (intermediate- up)

A group of students are taking a trip to somewhere. They use miming to share what items they need to take and each one is deputized for a position like the bus driver, the paramedic doctor, the tour guide, etc.

3. Putting a story into play (intermediate)
There are many stories that are perfect for this type of activity. Considering the proficiency level of the students, the teacher chooses a short story and assigns each student a role to play.

4. City official's round table (upperintermediate)

Every and each student is given a role to play, say the head of the police department, the mayor, representative of the school staff, etc. Students by different professional tags discuss problems of their neighbourhood, city or country.

In their article they formulated some valuable benefits for bringing drama to English language learner.

1. Drama puts new vocabulary and expression in their proper context and environment.

2. Drama helps in getting acceptable pronunciation and intonation in English.

3. Drama helps students to take responsibility for their own learning

4. Drama sets a stress free atmosphere to learn the language.

5. Drama encourages learners and builds up their confidence to speak in public.

6. Drama helps students to build a better understanding of the foreign language culture. 


\section{Drama for non-English students}

Shokri and Philip (2014) investigated undergraduates' perceptions on the implementation of drama activity in the tertiary English language courses. The focus was on the perceptions of learners ${ }^{e e}$ language development, confidence level, and teamwork skills acquired after involving drama productions.

After conducting the study they found that Engineering students strongly agree with ideas of drama improves communication skill, drama boosts selfconfidence, drama enhances social skills via teamwork, and drama is an enjoyable experience in learning English.

\section{Difficulties in understanding drama}

Shakfa (2012) explored problems faced by students in understanding drama. He found that a majority of the students agreed that "reading drama is more common than watching it." Students face this major difficulty in learning drama. Over $70 \%$ of the students agreed that "students feel frustrated with the length of a play," "Extensive use of symbolism, similes, metaphor," and "writing style" were serious problems.
He then concluded that acting out drama, rather than reading it, is an effective way in learning and teaching drama, should be taken into consideration in exposing the students to the theater. One way is to take the literature and drama students to the theatrical stage rather than remain inside the classrooms.

\section{CONCLUSION AND SUGGESTION}

Drama which is used to convey feelings and emotions has become a popular tool for learning language. There are a variety of activities using drama, including: miming, role play, simulation, and improvisation.

Drama is a valid technique which fosters students' interest and motivation by providing a relaxed and vivid environment and it also engages students' feelings and attention through experiencing the connection between action and thoughts. Drama encourages students to develop their creativity, strengthen their confidences, as well as improve the ability to cooperate with others.

Teaching English involves balancing input and output, drama is an effective tool to deal with this issue. Students have their own stage to express their thoughts and 
show their initiative. In drama class, the students' role becomes the center of the class. The teaching curriculum and all the activities are planned to satisfy the students' needs and interests.

Drama is considered a student centered and meaning based strategy. Some teachers confuse how to organize the activities, some teachers are afraid of losing in control the class, and some teachers worry about how to design the activities. Drama techniques offer innovative approaches to teachers and help them to be successful.

How to use drama technique in language classes becomes a considerable problem for teachers. Some research shows that it is meaningful for teachers to have command of drama techniques. Good techniques help students to be involved in the class actively and make the learning process vivid. There are at least three techniques to be followed: Teachers' responsibilities should be clear. Students can be the center of class instead of teachers. The teacher is just like a guide who directs students' action not far from authors' intents and can also create comfortable and welcoming atmosphere for students. Avoid detailed instruction for students. Take a specific example of a drama activity for teaching English: teachers divide students in pairs or groups and give them the planning time which can make the process efficient. Then students can choose their characters and create the situation and setting by themselves in the limited time.

This kind of active cooperation makes every student feel responsible for the task; even some low-level student will become confident and engaged when they take some role in the activity. Students' initiative will be explored through drama. They will concentrate more on their work instead of being distracted. The teachers' role is just a timer or conductor who is responsible for giving some directions. Student- centered classes will be well organized as soon as every student can be involved and motivated in the learning process.

There are also some concerns for designing drama activity in English classes. In some cases, students can be reluctant to be engaged in drama activities, as it may cause students and teachers to be in embarrassing situations. Thus, there are some concerns for teachers to think about: students' age, different language level, different personalities, and cultural bias. These factors may affect whether the drama activity design is effective or not. For example, when reading literature or a story, 
although students can have a good command of the meaning and sentence structures, they still feel frustrated about understanding, because of the cultural differences.

Drama activity should link with students' interests and experiences. Drama is an effective device for students to act out their real experiences. The real experience can make students understand the target content deeply. For an instance, if the teacher wants to teach children past tense, fairy tales will be a good selection for children. Children will be excited to choose the plots and teachers can help them to select props and scenery. Thus selected materials as well as comfortable, free environments can arouse students' interest and motivation.

Teachers can assess the effectiveness of drama activities by giving some comments on grammar and pronunciation at the end of activities. Some teachers resist on using drama, because they think drama is only a fun activity rather than learning. The linguistic competence need not be neglected. Evaluation is necessary through the activity. When students carrying on the role play or simulation, it is not appropriate to interrupt their performances, the teacher is a facilitator to make comments on their advantages and some inappropriate language use. At end of the class, students are encouraged to do self-assessment or do peer assessment. Then the teacher should conclude what students should pay attention. Furthermore, it may be useful to produce an examination system which emphasizes improving their writing, speaking and reading skills. Examination can take various forms such as analyzing the plot or making up the story.

To summarize, drama techniques play a significant role in teaching English. It is an appealing device to enrich teachers and students' experience to process English acquisition together. For students, drama improves their fluency, creativeness as well as communicative competence. For teachers, it is a challenging but effective strategy which facilitates every student to become more initiative learner in English as a Second Language classes.

\section{REFERENCES}

Albalawi, BR. (2014). Effectiveness of Teaching English Subject using Drama on the Development of Students' Creative Thinking . IOSR Journal of Research \& Method in Education (IOSR-JRME). Volume 4, Issue 6 Ver. I, PP 54-63. Retrieved from http://www.iosrjournals.org 
Moghaddas, Bahram and Ghafariniae, Reza. (2012). Applying Drama Techniques In Teaching English In Iran. International Journal of Social Science \& Interdisciplinary Research. Vol.1 Issue 9

Shakfa, MDA. (2012). Difficulties Students Face in Understanding Drama in English Literature at the Islamic University of Gaza (IUG). English Language Teaching. Vol. 5, No. 9
Shokri, NM and Philip, Alicia. (2014). Implementing English Drama For Engineering Students. International Journal of Asian Social Science.

Zyoud, Munther. (2011). Using Drama Activities and Techniques to Foster Teaching English as a Foreign Language: a Theoretical Perspective. Al Quds Open University. Retrieved from http://www.qou.edu 